\title{
Loforð og efndir
}

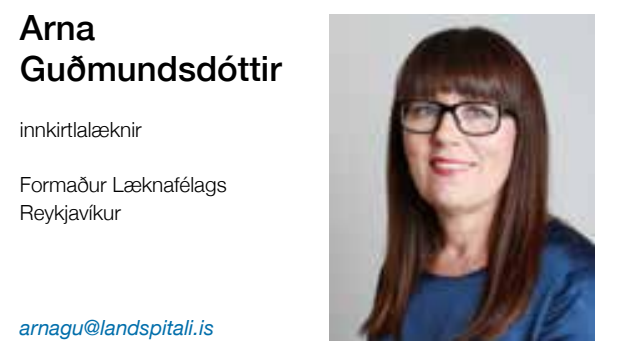

arnagu@landspitali.is

Allt bendir til pess að kosið verði til alpingis í lok október næstkomandi. Ekki er ólíklegt að staða og framtíð heilbrigðispjónustunnar á Íslandi verði eitt af stóru kosningamálunum og segja má að kominn hafi verið tími til. Miðað við vægi hennar í íslensku samfélagi og miðað við pann mikla metnað og samstöðu pjóðarinnar sem ítrekað hefur komið fram á síðustu árum er í raun illskiljanlegt að heilbrigðismálin hafi ekki skipað stærri sess í stjórnmálaumræðu undanfarinna áratuga en raun ber vitni.

Á pví hlýtur að verða breyting í aðdraganda peirra kosninga sem framundan eru. Um leið er ástæða til að láta í ljós pá von að umræðan verði málefnaleg og uppbyggjandi. Hitt verður pó að játast að pegar umræðuhefðin á vettvangi stjórnmálanna er skoðuð í heild sinni og ennpá frekar pegar horft er til opinberra skoðanaskipta um heilbrigðismál að undanförnu er engin sérstök ástæða til bjartsýni.

Í pessum efnum hef ég til dæmis í huga upphrópanakennda umræðu um eflingu heilsugæslunnar og próun í átt til aukins einkareksturs í heilbrigðispjónustunni. Mér er fyrirmunað að skilja hvers vegna peir stjórnmálamenn sem andsnúnir eru slíku rekstrarfyrirkomulagi leyfa sér til dæmis endalausar tilraunir til að setja samasemmerki á milli einkareksturs og einkavæðingar. Ég pekki engan Íslending og ennpá síður lækni sem vill hverfa frá pví sterka kerfi almannatrygginga og um leið peim jöfnuði sem einkennir íslenska heilbrigðispjónustu. Ég pekki hins vegar marga, og er ein af peim sjálf, sem telja ólík rekstrarform undir sameiginlegum hatti almannatrygginga og ríkisrekinnar heilbrigðispjónustu af hinu góða. Einkarekstur er eitt peirra. Einkavæðing kemst hins vegar ekki undir pann hatt samkvæmt skilgreiningu fjármálaráđuneytisins á hugtakinu. Svo einfalt er pað.

Heilbrigðiskerfið sem okkur öllum pykir svo mikilvægt hefur átt undir högg að sækja í langan tíma. Nú virðist langpráo lag til pess að snúa vörn í sókn og fyrstu skrefin í pá átt hafa raunar pegar verið stigin. En betur má ef duga skal og um pað virðast allir sammála. Pess vegna er svolítið einkennilegt að heyra á sama tíma pær úrtöluraddir að stíga verði varlega til jarðar, ekki megi auka á penslu í ríkisútgjöldum, vekja upp verðbólgudrauginn og annað álíka. Við höfum hvort tveggja í senn, góðar aðstæður og uppsafnaða pörf fyrir verulegan viðsnúning. Á meðan biðlistar eftir margskonar pjónustu eru langir, á meðan hjúkrunarrýmispjónustu við aldraða er verulega ábótavant og á meðan greiðslupátttaka almennings er langt umfram eðlileg mörk er engin afsökun til fyrir pví að bretta ekki upp ermar. Engin ástæða er pó til að leggja til gjaldfrjálsa pjónustu eins og sum stjórnmálaöfl hafa pegar freistast til að lofa. Eðlileg og hófstillt gjaldtaka með paki á heildarútgjöldum einstaklinga er pað sem parf.

Og pað eru fleiri ástæður sem hvetja til aðgerða. Háværar raddir hafa haldið pví fram að undanförnu að íslensku heilbrigðiskerfi og ekki síst Landspítalanum væri ógnað af pví sérhæfða sjúkrahúsi í eigu einkaaðila sem ef til vill mun rísa hér á næstu árum. Væntanlega er nokkuð til í pví. En hvers vegna stafar ógn af tilvist slíks fyrirtækis? Svarið er einfalt: Skortur á samkeppnishæfni. Enda pótt reynt væri að halda pví fram að bæði stæði til að flytja inn lækna og sjúklinga blasti pað auðvitað við að læknum og öðru heilbrigðisstarfsfólki á Íslandi yrði boðið að starfa á sjúkrahúsinu. Ef pað er talin ógn við heilbrigðiskerfið að fólki bjóðist störf annars staðar er rétt að skoða pað ofan í kjölinn hver hinn raunverulegi vandi er.

Talið um að íslenskum læknum myndi ekki bjóðast að starfa parna var auðvitað augljós og innihaldslaus fagurgali og rímaði á engan hátt við pað alpjóðlega umhverfi sem læknar bæði mennta sig og starfa í. Og pað leiðir hugann að pví hverjir séu í raun „íslenskir læknar“. Er íslenskur ríkisborgari endilega íslenskur læknir? Er sá sem mætir til leiks með háskólagráður sínar og áralanga sérfræðipjálfun til dæmis frá Svípjóð eða Bandaríkjunum íslenskur læknir eða er hann miklu frekar til dæmis sænskur eða bandarískur? Hvað um indverska lækninn sem starfað hefur á Íslandi í aldarfjórðung? Er hann íslenskur læknir, indverskur eða franskur af pví að hann menntaði sig par? Mikill meirihluti peirra lækna sem starfa hér á landi sækir sérfræðimenntun sína til virtra háskóla utan landsteinanna og standa peir sjálfir straum af öllum kostnaði ólíkt pví sem er í hinu niðurgreidda grunnnámi við Háskóla Íslands. Eftir starfskröftum pessara lækna er sóst víða um heim. Pað er að mínu viti bæði úrelt hugsun og hættuleg íslenska heilbrigðiskerfinu ef pað telur sig geta gengið að einhverjum hópi lækna vísum af pví að hann sé „íslenskur“. Allra síst er pað hægt ef aðbúnaður og kjör standast ekki alpjóðlegan samanburð og hætta pykir jafnvel á hruni kerfisins ef einkavædd (sem er allt annað en einkarekin!) heilbrigðisstarfsemi ákveður að drepa niður fæti hér á landi. Pess vegna skipta bæði loforð og efndir frambjóðenda og pingmanna miklu máli á næstu mánuðum og misserum. Мeð hvoru tveggja verður fylgst af athygli.

Campaign promises and delivery

Arna Guðmundsdóttir, MD Consulting Physician Department of Endocrinology \& Metabolism Landspítali - University Hospital Fossvogi 107 Reykjavik Iceland 